\title{
Narghile smoking keeps researchers in Wonderland*,**
}

\author{
0 uso de narguilé mantém pesquisadores no País das Maravilhas
}

\section{To the Editor:}

The recent debate between Rodrigues and Viegas, published in this journal, ${ }^{(1)}$ shows that the field of research in question-narghile smoking, also known as hookah, or shisha, smoking-has, against the backdrop of a global epidemic, reached a high degree of confusion. The two authors discuss the volumes of smoke, nicotine, tar, etc. However, the cited referencesespecially those from the American University of Beirut-are actually behind the abovementioned confusion. Viegas knows that this description of the water-pipe smoking simulator has been criticised, since two of his cited references (Khater et al. and Chaouachi) are explicit in this respect. ${ }^{(1)}$ In contrast, Rodrigues seems to ignore such criticism, probably for the very reasons he gives: the fact that antismoking public health campaigns would be unethical. For instance, he cites the World Health Organization (WHO) report without realizing that a detailed peerreviewed critique, discussing all of the moot questions regarding tar, nicotine, addiction, etc., has been published. ${ }^{(2)}$ Notably, the critique shows that the high volumes of smoke bear little relation to nicotine, and that narghile smoking is much less addictive than is cigarette smoking, as stated elsewhere. ${ }^{(3,4)}$

It is difficult to make a truly scientific comparison between cigarette smoking and narghile smoking. The former contains thousands of chemicals, whereas the latter is far less complex, composed primarily $(80 \%$ or more) of dihydrogen monoxide and glycerol (no biological activity). The same could be said for comparisons between smoking and exposure to environmental tobacco smoke. ${ }^{(4)}$ The dismissal, in the WHO report, of early scientific works by the most prominent tobacco and cancer specialists (Wynder, Hoffmann, Rakower, Roffo, Sanghvi,

\footnotetext{
* The title of this letter refers to a paper mostly based on anecdotes, though often cited in the mainstream literature: Kandela P. Nargile smoking keeps Arabs in Wonderland. Lancet. 2000;356(9236):1175.

** A versão completa em português deste artigo está disponível em www.jornaldepneumologia.com.br
}

etc. ${ }^{(2)}$-also known as "publication bias" in the field of editorial ethics-has been detrimental to the credibility of public health interventions.

The problem lies not only in "the general error [of]... selecting bits of information..." and "[ignoring]... diverse methodologies..." (1) but also in the information sources themselves, which have been repeatedly cited by many researchers. As an initial example, the study on narghile radioactivity (Khater et al., 2008), cited by Viegas, ${ }^{(1)}$ has established that the 100 million narghile daily user figure (mentioned, together with other errors, in the Cochrane "waterpipe" review) has in fact no scientific peer-reviewed source. As another example, there has been, since 1967, an open and often heated debate regarding the international standard cigarette smoking simulator (which draws only a few puffs spaced $60 \mathrm{~s}$ apart). However, it is amazing that the relevancy of a laboratory "model" based on a narghile smoking machine (American University of Beirut) drawing smoke every $17 \mathrm{~s}$ for a full hour with the heating source (coal) in the same position, has hardly been called into question. (1,5) Listings of the yields for aldehydes, polycyclic aromatic hydrocarbons, etc., have been widely accepted with no discussion. The following questions should have arisen: "Is a narghile smoker a robot?"; "Is this "standardized' (sic) machine realistic?"; and "If the model of a cigarette smoking machine based on a 5 min session has been rejected, how can the relevancy of a 60-min narghile smoking machine be substantiated?" Nevertheless, peer-reviewed critiques of the underlying smoking topography exist. ${ }^{(5)}$

Therefore, the questions raised by Rodrigues are perfectly justified. In addition, it should be borne in mind that shorter inter-puff smolder times translate to greater tar production. $1 t$ is not surprising that no experience with an inter-puff smolder time of $1 \mathrm{~min}$ or more has ever been advertised. In fact, narghile smoking machines set with different parameters have revealed completely different toxicant yields. ${ }^{(5)}$ For instance, Sanghvi, a renowned cancer specialist, long ago performed a smoke chemical analysis 
for tar and nicotine and stressed that "[the] results were comparable to those for some of the mildest cigarettes on the world market and show the efficiency of water as a filter". ${ }^{(6)}$ This important experiment was never cited in the mainstream literature.

Tobacco smoking is quite dangerous. However, it cannot be said to be "deadly in any form or disguise". The best counter-example is smokeless tobacco of the Swedish snus type, which could save the lives of millions, particularly in Asia and Africa, where low-quality smokeless products are being used with no safer (not "safe") alternative. ${ }^{(3)}$ The rejection of harm reduction products (Eclipse cigarette, snus, E-cigarette, etc.) is unethical from a public health viewpoint. Regarding narghile smoking, the main clearly and early identified public health problem is carbon monoxide, for which no public recommendations have been issued for more than 10 years. ${ }^{(4)}$ Narghile smoking has major human, social and cultural dimensions. ${ }^{(2)}$ Rodrigues should be thanked -as well as the Brazilian Journal of Pulmonology, which opened its columns to the voice of dissent, despite the fact that the dissent originated from the Humanities field. An excessively positivist view, rejecting any debate-the condition of scientific progress-in this field has been detrimental in view of the world epidemic. Perhaps a quote from Descartes (related to the radical method of doubt) or Voltaire (in defense of his own opponents) would have been more appropriate than a quote from Marguerite Yourcenar. ${ }^{(1)}$

\author{
Kamal Chaouachi \\ Chargé de Cours à la \\ Faculté de Médecine de Paris Sud \\ (DIU de Tabacologie), \\ Paris, France
}

\section{References}

1. Rodrigues AA. To convince and to inform: ethical issues in public health campaigns. J Bras Pneumol. 2009;35(4):396-7; author reply 397-8.

2. Chaouachi K. A critique of the WHO TobReg's "Advisory Note" report entitled: "Waterpipe tobacco smoking: health effects, research needs and recommended actions by regulators". J Negat Results Biomed. 2006;5:17.

3. Sajid KM, Chaouachi K, Mahmood R. Hookah smoking and cancer: carcinoembryonic antigen (CEA) levels in exclusive/ever hookah smokers. Harm Reduct J. 2008;5:19.

4. Chaouachi K. Hookah (Shisha, Narghile) Smoking and Environmental Tobacco Smoke (ETS). A critical review of the relevant literature and the public health consequences. Int J Environ Res Public Health. 2009;6(2):798-843. Epub 2009 Feb 23.

5. Chaouachi K. Public health intervention about narghile (hookah, shisha) requires a radical critique of the related "standardised" smoking machine. J Public Health (Dresden). [Online First, 17 Jul 2009].

6. Sanghvi LD. Cancer epidemiology: the Indian scene. J Cancer Res Clin Oncol. 1981;99(1-2):1-14. 